\title{
PRIME-TIME FAMILIES
}


This page intentionally left blank 


\title{
PRIME-TIME FAMILIES
}

\author{
Television Culture \\ in Postwar America
}

ELLA TAYLOR

University of California Press

Berkeley Los Angeles London 
This book is a print-on-demand volume. It is manufiactured using toner in place of ink. Type and images may be less sharp than the same material seen in traklitionally printed University of California Press editions.

University of California Press

Berkeley and Los Angeles, California

University of California Press, Ltd.

London, England

1989 by

The Regents of the University of California

\section{Library of Congress Cataloging-in-Publication Data}

Taylor, Ella.

Prime-time families : television culture in postwar America/Ella Taylor.

p. $\mathrm{cm}$.

Based on the author's thesis (Brandeis University).

Bibliography: $\mathrm{p}$.

Includes index.

ISBN 978-0-520-07418-7 (alk. paper)

1. Television and family-United States. 2. Television serialsUnited States. I. Title.

PN1992.8.F33T39 1990

$302.23^{\prime} 45^{\prime} 0973-\mathrm{dc} 20$

Printed in the United States of America

The paper used in this publication meets the minimum requirements of ANSU/NISO Z39.48-1992 (R 1997 ) (Permanence of Paper). 
For my parents,

Hannah and Sol Gafan,

who, by creating quiet time and space

in which to do homework,

turned their daughter into an intellectual 
This page intentionally left blank 